\title{
Harmadik hullám
}

DOI: $10.19055 / \mathrm{ams} .2014 .5 / 12-13 / 1$

Immár hat éve, 2008-ban indult az a kutatássorozat, melynek célja a Nyíregyházán élő felnőtt népesség életminőségének vizsgálata. 2008 és 2010 után, harmadjára 2012-ben is alkalom nyílt arra, hogy a Nyíregyháza Megyei Jogú Város Polgármesteri Hivatala Szociális és Köznevelési Osztály és a Debreceni Egyetem Egészségügyi Kar Társadalomtudományi Tanszéke közremüködésével megvalósuljon a korábban tervezett, kétévente végzendő adatgyüjtés.

Az első két hullám adatainak feldolgozását tartalmazza az Életminőség Nyíregyházán címmel 2012-ben megjelent tanulmánykötet, melyet jelenlegi kötetünk, a 2012-es adatok alapján készített írások gyüjteménye követ. Ezzel további lépést tettünk egyik vállalt célunk teljesítése felé, hiszen úgy gondoltuk, hogy a Társadalmi Riport könyvsorozat mintájára mi is egy kétévente megjelenő sorozatot indítunk el.

Jelenlegi kötetünk tanulmányai ugyanannak a háztartáspanel mintának az eredményeire épülnek, melyet a korábbiakban is használtunk. A módszertan panel jellegét megtartva tehát 2012-ben is elsődlegesen háztartásokról, másodsorban pedig a háztartástagok bizonyos jellemzőiről gyüjtöttünk adatokat. Ahogyan más, akár nagyobb léptékü kutatásoknál is megfigyelhető, az eredetileg használt minta kérdezésről kérdezésre kopik: nagy a lakóhelyi mobilizáció, sok a válaszmegtagadás. Ez vonatkozik arra a panel mintára is, amellyel mi dolgoztunk.

\begin{tabular}{|c|c|c|c|}
\hline & $\mathbf{2 0 0 8}$ & $\mathbf{2 0 1 0}$ & $\mathbf{2 0 1 2}$ \\
\hline Háztartások száma & 1848 & 1060 & 1227 \\
\hline Személyek száma & 4866 & 3066 & 2930 \\
\hline
\end{tabular}

A minta alakulása

A panelkutatásoknak megfelelően, a háztartásokra vonatkozó adatokat súlyozatlan, míg a személyekre vonatkozó adatokat súlyozatlan adatbázis alapján dolgoztuk fel. 
A nyíregyházi panelkutatás tervezésekor és mindenkori kivitelezésekor figyelmet fordítottunk arra, hogy adataink ne csupán a városról szóljanak, hanem valamilyen viszonylatban is értelmezhetők legyenek azok a jellegzetességek, mintázatok, melyek az egyes években leírják a nyíregyházi felnőttek életminőségét. Ezért alapul a hazai és a nemzetközi előzményeket vettük, annak módszertanát, sok esetben kérdéseit alkalmaztuk a sok szempontú összehasonlítás érdekében. A véglegesített kérdőív a Szociális Iroda munkatársainak illetve a Társadalomtudományi Tanszék oktatóinak a közös munkája, mely a korábbi évekhez hasonlóan, továbbra is a következő nyolc blokkban vizsgálta a városiak életminőségét:
1. Háztartásokra vonatkozó kérdések
2. Gazdasági aktivitás
3. Egészségi állapot
4. Társas kapcsolatot
5. Idősek helyzete
6. Támogató rendszerek - szociális problémák
7. Szociális Osztály müködése
8. Biográfia

A kérdőívek lekérdezésében 2012-ben is a Debreceni Egyetem Egészségügyi Kar különböző szociális képzéseiben résztvevő hallgatók müködtek közre, melyet ez úton is köszönünk. A kérdezés sikerességét elősegítendő, a korábbi évek gyakorlatát követve, 2012-ben is polgármesteri levélben értesítettük a mintába bekerülő háztartásokat arról, hogy egy bizonyos időszakban kérdezőbiztos keresi fel őket. A kutatásban bekerülők a kérdezés céljáról, lényegéről is értesültek a levélben.

Tanulmánykötetünkben a korábbihoz hasonló módon, igyekeztünk a fentebb említett tematikus blokkok mentén bemutatni a 2012-es kutatás eredményeit. A kötetben szereplő tanulmányok kereteként, egyfajta bevezetőként jelenleg is egy átfogó dolgozat szerepel, melyben Malakucziné Póka Mária a 2011-es népszámlálásnak a Nyíregyházára vonatkozó adatait mutatja be és elemzi. Az írás részletesen foglalkozik Nyíregyháza Megyei Jogú Város demográfiai és háztartási jellemzőivel, képet ad a 2001-es népszámlálás óta eltelt változásokról a családokkal, illetve az egyének iskolai végzettségével kapcsolatban.

R. Fedor Anita és Jávorné Erdei Renáta munkájukban a nyíregyházi felnőtt népesség gazdasági aktivitásának jellemzőit mutatják be elsősorban a nyíregyházi vizsgálat három hullámának adataira támaszkodva, melyek lehetőséget adtak a munkaerő-piaci jellemzők összehasonlító elemzésére. A szerzők a gazdasági 
aktivitás témakörén belül részletesen foglalkoznak a helyi foglalkoztatási, munkanélküliségi tendenciák bemutatásával, a háttértényezők vizsgálatával.

Fábián Gergely, Takács Péter és Szigeti Fruzsina tanulmánya a jövedelmi helyzet változásával, a társadalmi polarizálódás jellemzőivel foglalkozik elsősorban a városi adatfelvétel "hullámaira" építve, de kitekintve az országos adatokra is. Az írás egyik fontos momentuma, hogy a szerzők többféle mutató részletes vizsgálatával elemzik a jövedelmi egyenlőtlenségek változásait.

Szilicsány Éva Panna az anyagi depriváció különböző indikátorainak segítségével azt vizsgálja, hogy milyen megfosztottságok vannak jelen 2012-ben a nyíregyházi népesség körében, ezek hogyan halmozódnak a kirekesztődés kockázati tényezőjét jelentő súlyos anyagi deprivációvá.

Balogh Erzsébet és R. Fedor Anita a szociális védelemre fordított kiadások alakulását vizsgálják tanulmányukban, mely során külön kitérnek a helyi önkormányzatok szociális segélyezési kiadásainak részletezésére is. A nyíregyházi háztartáspanel adataira támaszkodva foglalkoznak a segélyezési típusok igénybevételi gyakoriságával, jellemzőivel, továbbá annak vizsgálatával, hogy a városlakók hogyan értékelik az igénybe vehető segélyek hatékonyságát. A tanulmány képet ad arról is, hogy vajon a megkérdezettek hogyan alakítanák át a segélyezésre való jogosultság feltételeit.

Szoboszlai Katalin a panel vizsgálat és a 2011-es népszámlálás eredményei alapján jellemzi a város lakáshelyzetét. A szerző foglalkozik a lakónépesség és a lakások számának változásaival, a tulajdonviszonyokkal, a város bérlakás állományának bemutatásával, részletezi a lakások felszereltségét, továbbá a társadalmi rétegződés és a különböző lakókörzetek közötti összefüggést taglalja.

Patyán László az egyszemélyes háztartásokban élő idősek életminőségét elemzi objektív és szubjektív szempontból is. A szerző a városi adatok részletes bemutatásán kívül kitér a lehetséges pontokon szóba jöhető hazai és nemzetközi kutatásokra, azok eredményeire. A tanulmány az életminőséget determináló főbb mutatók mentén elemzi a célcsoportot, így kitér a jövedelem, az egészségi állapot, a lakhatás, a különböző szolgáltatások, valamint a szubjektív jólét jellemzőinek bemutatására.

Huszti Éva a társas kapcsolatok változásairól ad képet a nyíregyházi vizsgálatokból származó adatok részletes elemzésével. A szerző a rokoni és nem rokoni kapcsolatok alakulását vizsgálja az olyan, inkább erős kapcsolatokra fókuszálva, mint a családtagokkal, rokonokkal, barátokkal való kapcsolattartás jellemzői. 
Ezen kívül a nyíregyházi felnőtt népesség közéleti aktivitása, illetve a magántársasági összejövetelek gyakorlata kerül még tárgyalásra.

Fábián Gergely és Takács Péter jelen tanulmányukban továbbra is a korábbi kötetben bemutatott FT lokális életminőség index-szel foglalkoznak. A szerzők ismertetik az életminőséget vizsgáló méréseket, modelleket, továbbá az index eddigi alkalmazásából származó kutatási eredményeket. A tanulmány külön foglalkozik a különböző generációk életminőségi mutatóival.

Jávorné Erdei Renáta, R. Fedor Anita, Berencsiné Madácsi Eszter a nyíregyházi felnőtt népesség szubjektív egészségi állapotáról, annak változásairól ad képet. A szerzők külön részletezik a nemek közötti szubjektív egészségi állapot különbségeit illetve az iskolai végzettségből fakadó eltéréseket. Ezen túl kitérnek a nyíregyháziakra jellemző háziorvoshoz fordulás, illetve a dohányzás gyakoriságának bemutatására, foglalkoznak a nők különböző szürővizsgálaton való megjelenésének jellemzőivel.

Hüse Lajos írása kissé eltér a többi tanulmánytól, hiszen a szerzö "kilép" a nyíregyházi panelvizsgálat adta keretekből, ugyanakkor több szempontból kapcsolódik a kötet más tanulmányaihoz. A bemutatott elemzés adatbázisát egy olyan program során lebonyolított kutatás adja, melynek elsődleges célja az volt, hogy közelebb hozza egymáshoz az enyhe és középsúlyos értelmi fogyatékos, illetve az ép gyermekeket. A tanulmány az értelmi fogyatékkal élő gyermekek és családjaik életminőségét befolyásoló tényezőkkel foglalkozik, egészen pontosan az inkluzív oktatás hatásaival.

A kötet szerkesztői továbbra is annak reményében indítják útnak a kiadványt, hogy a tisztelt olvasók hasznos és érdekes információkat kapnak egyrészről egy lokális, csak a nyíregyháziakat jellemzö életminőség számos paraméteréről, másrészt egy kis globális kitekintéssel a hazai és nemzetközi tendenciákba is bepillantást nyerhetnek. Úgy gondoljuk, hogy elemzéseink hozzájárulhatnak számos tanulmány, pályázati program kialakításához, fejlesztéséhez.

Huszti Éva

Fábián Gergely 